\title{
Constraints Faced by Farmers in Goat Rearing Practices in Jaipur District of Rajasthan, India
}

\author{
Mamta Kumawat ${ }^{1}$, Athar Uddin ${ }^{1}$, Rashmi Bhinda ${ }^{1 *}$, \\ Shankar Lal Khichar ${ }^{2}$ and Ganesh Ram Jat \\ ${ }^{1}$ Department of Livestock Production Management, SKNAU, Jobner, Jaipur, India \\ ${ }^{2}$ Department of Animal Husbandary and Dairying, IAS, BHU, Varanasi, India \\ *Corresponding author
}

\section{A B S T R A C T}

\section{Keywords}

Constraints, Goat

farmers.

Article Info

Accepted:

10 October 2017

Available Online:

10 December 2017
The present study was conducted in Jaipur district of Rajasthan, to find out the constraints faced by farmers in goat rearing practices. For this, fifty farmers were selected and information was collected with the help of structured interview schedule and data was analyzed with the appropriate statistical tools as; mean, percent score and chi square were drawn from it. It was found that farmers were faced constraints related to feeding, breeding, health and management.

\section{Introduction}

The goat (Capra hircus) is recognized as "Movable Wealth" for nomads, small and marginal farmers and land less labours. It has tremendous potential and projected as the 'Animal of Future' for rural prosperity and its rearing is a good subsidiary occupation. India is ranked as the second-largest in goat population in the world having 135.17 million goats. The population of goat has declined by 3.82 per cent over the previous census (Anonymous, 2012). Goat farming is the best choice for the rural people in developing countries because of the low investment, wide adaptability, high fertility and fecundity, low feed and management needs, high feed conversion efficiency, quick pay-off and low risk factors. Goat is one of the major livestock species contributing to the livelihood security of farmers in Rajasthan. They can thrive well in adverse climatic conditions using sparse vegetation.

Goats are mainly reared by socially and economically backward people of the society for whom they act as a store of wealth of high liquidity, a resource for meeting the household nutritional security and a source of regular income.

The farmers rear goat mainly in extensive management system using traditional management practices relying on community land for grazing and are yet ignorant of scientific management practices. The 
adoption of improved management practices specially improved feeding, breeding and other management practices not only help to achieve thedesired level of goat production but also increase income of farmers (Dudi and Meena, 2013).

The goat keepers needed training on breeding and health care to a greater extent to improve the production from goats. Hence, extension agencies should disseminate information based on training needs at the field conditions for livelihood security of the farmers (Meena and Singh, 2015).

\section{Materials and Methods}

The study was conducted in Jobner area of Jaipur district of Rajasthan. Four villages namely Jorpura, Naga ji ki Dhani, Baberbalo ki Dhani and Sursinghpura were selected considering their distance from goat unit of S.K.N. College of Agriculture, Jobner at 1.5, 2.0, 2.5 and $5.0 \mathrm{~km}$ respectively. Fifty farmers having goats were randomly selected for interview from each village and information regarding their management practices were collected on prescribed schedule.

Table.1 Constraints faced by goat farmers and suggestion for improvement

\begin{tabular}{|l|l|c|c|c|c|}
\hline S. & \multirow{2}{*}{ Village } & \multicolumn{3}{|c|}{ Constraints faced by goat farmers } \\
\cline { 3 - 6 } & & $\mathbf{C 1}$ & $\mathbf{C 2}$ & $\mathbf{C 3}$ & $\mathbf{C 4}$ \\
\hline $\mathbf{1}$ & Baber walo ki Dhani & $26(52 \%)$ & $08(16 \%)$ & $11(22 \%)$ & $05(10 \%)$ \\
\hline $\mathbf{2}$ & Sursinghpura & $09(18 \%)$ & $14(28 \%)$ & $10(20 \%)$ & $17(34 \%)$ \\
\hline $\mathbf{3}$ & Naga ji ki Dhani & $15(30 \%)$ & $20(40 \%)$ & $05(10 \%)$ & $10(20 \%)$ \\
\hline $\mathbf{4}$ & Jorpura & $06(12 \%)$ & $09(18 \%)$ & $18(36 \%)$ & $17(34 \%)$ \\
\hline & Total & 56 & 51 & 44 & 49 \\
\hline & Av. Of villages & 14 & 12.75 & 11 & 12.75 \\
\hline & Per cent of farmers & 28.0 & 25.5 & 22.0 & 24.5 \\
\hline
\end{tabular}

$\chi^{2}=40.037$ (Significant)

$\mathrm{C} 1=$ Related to feeding \& breeding, $\mathrm{C} 2=$ Related to health and breeding, $\mathrm{C} 3=$ Related to health and management, $\mathrm{C} 4=$ Related to feeding, breeding, health and management

\section{Results and Discussion}

Constraints faced by farmers and suggestion for improvement

Table 1 shows that the 28 per cent goat farmers feel constraints related to feeding \& breeding, $25.5 \%$ related to health and breeding, $22.0 \%$ related to health and management, and $24.5 \%$ related to feeding, breeding, health and management. The calculated chi-square value was more than tabulated value at 5 per cent level of significance. Hence, the difference is significant agreement between the villages with regards to constraints faced by goat farmers. Tanwar (2011) reported that the main constraint regarding feeding management was lack of knowledge about balanced feeding, high cost of feeds and fodder, lack of irrigation facilities, non-availability of green fodder, lack of knowledge about importance of mineral mixture, and shrinking grazing land. Regarding breeding, main constrains were inadequate availability of breeding buck, lack of knowledge about breeding practices and indiscriminate breeding practice. With respect to health care the major constraints were lack of veterinary services in villages, high cost of treatment, ignorance about importance of deworming, lack of knowledge about common diseases and vaccination programme not carried out by any agency in semiarid part of Rajasthan. Similar findings 
were also reported by Kumar et al., (2015) and Narmata et al., (2013) the scarcity of green fodder $(78.57 \%)$, diminishing grazing areas $(77.86 \%)$ in Namakkal district of Tamil Nadu. Poornima et al., (2015) observed that the High cost of mineral mixture was cited by the respondents as the next most important constraint followed by non-availability of green fodder throughout the year and high cost of fodder in Almora district of Uttarakhand. Suresh et al., (2008) also reported that major constraints in the input side were fodder scarcity, high price of feed as well as unavailability of quality medicines in semiarid region of Rajasthan. The results of present study are also corroborate with the findings of Jana et al., (2014), Narain et al., (2015) and Sabapara et al., (2014).

\section{References}

Anonymous, 2012. $19^{\mathrm{TH}}$ Livestock all India report. Ministry of Agriculture Department of Animal Husbandry, Dairying and Fisheries Krishi Bhawan, New Delhi. pp. 11-23.

Dudi, Aishwarya and Meena, M.L., 2013. Adoption of improved goat production practices by goat keepers. Indian Journal of Small Ruminants, 19 (2): 235-237.

Jana, C., Rahman, F. H., Mondal, S. K. and Singh, A. K. 2014. Management practices and perceived constraints in goat rearing in Burdwan District of West Bengal. Indian. Res. J. Ext. Edu., 14 (2): 107

Kumar, V., Braj M., Dixit, A.K., Singh, khushyal, Kumar C., U.B. and Goel, A.K. 2015. Goat farming status: A benchmark survey in adopted village of Mathura district of Uttar Pradesh. Indian Journal of Small Ruminants, 21 (1):158-160.

Meena, M.L. and Singh, D. 2015. Training needs of goat keepers in Marwar Region of Rajasthan. Indian Journal of Small Ruminants, 21(1):161-164.

Narain, Sarju, Rawat and Kumar, S. 2015. Adoption of improved goat keeping practices in Jalaun District of U.P. Agro Economist: An International Journal, 2 (1) 7-10

Narmatha, N. Sakthivel, K.M., Uma, V. and Akila, N. 2013. Adoption and constraints in improved goat rearing practices. Indian Journal of Animal Research, 47 (6): 547-550.

Poornima, S., Bardhan, D., Kumar, A. 2015. Constraints faced by goat farmers in Almora district of Uttarakhand. Indian Journal of Small Ruminants, 21 (2): 325-330.

Sabapara, G.P., Sorthiya, L.M. and Kharadi, V.B. 2014. Constraints in goat husbandry practices by goat owners in Navasari district of Gujarat. International Journal of Agriculture Science and Veterinary Medicine, 3 (2) 32-36.

Suresh, A., Gupta, D.C. and Mann, J.S. 2008. Constraints in adoption of improved management practices of sheep farming in semi-arid region of Rajasthan. Indian Journal of Small Ruminants, 14 (1): 9398.

\section{How to cite this article:}

Mamta Kumawat, Athar Uddin, Rashmi Bhinda, Shankar Lal Khichar and Ganesh Ram Jat. 2017. Constraints Faced by Farmers in Goat Rearing Practices in Jaipur District of Rajasthan, India. Int.J.Curr.Microbiol.App.Sci. 6(12): 942-944. doi: https://doi.org/10.20546/ijcmas.2017.612.103 